\title{
CORPUS Corpus
}

Archivos virtuales de la alteridad americana

Vol 5, No $1 \mid 2015$

Enero / Junio 2015

\section{Deslizándose en las fisuras de la utopía: los Toba en las fronteras del Estado Nación argentino}

En se glissant dans les fissures de l'utopie : Les Tobas aux frontières de l'Etat Nation argentin

Slipping into the cracks of utopia : the Toba on the borders of the Argentinean nation state

\section{Carlos Salamanca}

\section{OpenEdition}

\section{Journals}

Electronic version

URL: http://journals.openedition.org/corpusarchivos/1422

DOI: $10.4000 /$ corpusarchivos. 1422

ISSN: 1853-8037

\section{Publisher}

Diego Escolar

\section{Electronic reference}

Carlos Salamanca, « Deslizándose en las fisuras de la utopía: los Toba en las fronteras del Estado Nación argentino ", Corpus [En línea], Vol 5, No 1 | 2015, Publicado el 30 junio 2015, consultado el 07 mayo 2020. URL : http://journals.openedition.org/corpusarchivos/1422 ; DOI : https://doi.org/ $10.4000 /$ corpusarchivos. 1422

This text was automatically generated on 8 May 2020.

Licencia Creative Commons: Atribución-NoComercial 2.5 Argentina (CC BY-NC 2.5 AR) 


\section{Deslizándose en las fisuras de la utopía: los Toba en las fronteras del Estado Nación argentino}

En se glissant dans les fissures de l'utopie: Les Tobas aux frontières de l'Etat Nation argentin

Slipping into the cracks of utopia : the Toba on the borders of the Argentinean nation state

Carlos Salamanca

\section{EDITOR'S NOTE}

TESISTA: Carlos Arturo Salamanca Villamizar

DIRECTOR: Marc Augé y Michel Agier

GRADO: Doctor en antropología social y etnología

INSTITUCION: École des Hautes Etudes en Sciences Sociales. EHESS.

FECHA DE DEFENSA: 27/06/2006

CIUDAD: París

\section{Breve comentario de introducción a la tesis}

1 Pensada, elaborada, sentida y escrita entre el 2000 y el 2006, esta tesis refleja las que entonces eran mis reflexiones, inquietudes y búsquedas.

2 Cuando fui invitado por Diego Escolar a enviar la tesis para su publicación en la revista Corpus, me resistí a la tentación de editarla, recortarla o revisarla. De abrir la puerta, algunos apartes los hubiera escrito de otro modo, algunas conclusiones las hubiera matizado, de otros hilos y otras hipótesis hubiera tirado un poco más. Pero lo escrito, 
escrito está, y opté por considerar esta tesis, no como el final de un camino, sino como parte de un proceso en el que aun me encuentro.

3 Hoy, a casi a diez años de haber finalizado dicha etapa mantengo una intensa relación con el Chaco; intensa, paradójica y contradictoria, llena de ausencias, amistades inquebrantables, rabias, tristezas, alegrías. Intuyo que es ésta intensidad la que me ha impedido volver sobre estas líneas para darles el destino que merecen; tal vez esta publicación constituya el impulso necesario.

4 De cualquier forma, quiero agradecer a Rosario Espina quien me impulsó a retomar la tesis y me confrontó con la necesidad de ponerla a circular. A su vez, quiero agradecer a Diego Escolar y al comité editorial de Corpus por haberla aceptado para su publicación.

5 Buenos Aires, 30 de junio de 2015.

\section{ABSTRACTS}

Done in the Argentinean Chaco, this thesis analyzed the relationship between space, social relations and political action. For this, we focus on the relationship between toba people and the Argentine nation-state. The space has been addressed in this thesis recognizing its heterogeneous condition, formed from the synchronous existence of multiple societies and different spaces. Unveiling the strength of utopian thinking in the consolidation of the nation state and the foundation of all relationships it has established with the natives, we analyze the process of constitution of the Argentinean Nation Argentina in Chaco and its characteristics universalist utopia. The analysis of the construction of the nation state and the historical development of the toba has been made going beyond the idea of the existence of an a-historical status of indigenous peoples and those studies focusing on the discipline/transgression, natural space as/socially built space and hegemony/resistance oppositions. Focusing on their forms of political action, we argue that the toba reveal the cracks in the nationalist utopia. We hold the view that in its relations with the Nation, Toba 'mariscan' [gather shellfish] in the areas of political action and proceed to the manufacture their collective identities by subjectivizing universalisms. Such universalisms are inherent to citizenship, indigenism, evangelism and sociopolitical movements called together from the social class, all of these being 'relational political devices' in which toba people put at stake contemporary political action.

Realizada en el Chaco argentino, en esta tesis analizamos las relaciones entre espacio, relaciones sociales y acción política. Para esto nos centramos en la relación entre los toba y el Estado-Nación argentino. El espacio ha sido abordado en esta tesis reconociendo su condición heterogénea, constituida a partir de la existencia sincrónica de múltiples sociedades y espacios diferentes. Develando la fuerza del pensamiento utópico en la consolidación del Estado-nación y en los fundamentos de todas las relaciones que éste ha establecido con los indígenas, analizamos el proceso de constitución de la Nación argentina en el Chaco y sus características de utopía de carácter universalista. El análisis de la construcción del Estado Nación y del devenir histórico de los toba ha sido realizado sobrepasando la idea de la existencia de un estado a-histórico de los indígenas y los estudios centrados en la oposiciones disciplina/trasgresión, espacio natural dado/ espacio social construido y hegemonía/resistencia. Centrándonos en sus formas de acción política, argumentamos que los toba develan las fisuras de la utopía nacionalista. Sostenemos la 
tesis de que en sus relaciones con la Nación los toba 'mariscan' en los espacios de acción política y proceden a la fabricación de sus identidades colectivas a través de la subjetivación de los universalismos. Tales universalismos son inherentes a la ciudadanía, el indigenismo, el evangelismo, y los movimientos político-sociales convocados a partir de la clase social, siendo todos estos 'dispositivos políticos relacionales' en los que los toba se juegan la acción política contemporánea.

\section{INDEX}

Palabras claves: toba-qom, Chaco, espacio, política, historia

Keywords: toba-qom people, Chaco, space, politics, history

\section{AUTHOR}

\section{CARLOS SALAMANCA}

Programa Espacios, Políticas y Sociedades, Centro de Estudios Interdisciplinarios, Universidad Nacional de Rosario- Consejo Nacional de Investigaciones Científicas y Técnicas (CONICET), Argentina.

Correo electrónico: salamanca.carlos@gmail.com 